\title{
An Infant with Multiple Congenital Anomalies and a Ring Chromosome in Group C (X-6-12)
}

\author{
L. J. BUTLER, N. E. FRANCE, and N. M. JACOBY \\ From Queen Elizabeth Hospital for Children, Hackney Road, London E.2, and Pembury Hospital, Kent
}

The occurrence in man of a ring chromosome replacing an autosome has been reported only rarely. Although three examples have involved a Group D (13-15) chromosome (Wang, Melnyk, McDonald, Uchida, Carr, and Goldberg, 1962; Bain and Gauld, 1963; Smith-White, Peacock, Turner, and Den Dulk, 1963) and four an ' $E$ ' Group (16-18) chromosome (Wang et al., 1962; Lucas, Kemp, Ellis, and Marshall, 1963; Genest, Leclerc, and Auger, 1963; Gropp, Jussen, and Ofteringer, 1964), they had few clinical features in common except for mental retardation. Partial deletion of chromosome No. 1 due to ring formation has been described in a microcephalic dwarf (Gordon and Cooke, 1964), while Rohde and Tompkins (1965) have reported a ring 5 chromosome in a case of 'cri-du-chat' syndrome. Two cases with a C-group ring autosome were recently described (Atkins, Pant, Hazard, and Ouellette, 1966), one showing an associated B/C translocation.

Ring $\mathrm{X}$ chromosomes appear to be equally rare, the only seven patients recorded having an $\mathrm{XO} / \mathrm{XX}_{\mathrm{R}}$ configuration (Lindsten and Tillinger, 1962; Lüers, Struck, and Nevinny-Stickel, 1963; Hustinx and Stoelinga, 1964; Pfeiffer and Büchner, 1964; Fisher, 1965; Bain, Gauld, and Farquhar, 1965; Bishop, Blank, Simpson, and Dewhurst, 1966). Most of them showed features of Turner's syndrome. A further case (Turner, 1963) had a ring chromosome in group C (X-6-12) which was probably not an $\mathrm{X}$.

\section{Case Report}

This female child was the result of a normal pregnancy and was delivered spontaneously at term weighing $2605 \mathrm{~g}$. ( $5 \mathrm{lb} .12 \mathrm{oz}$.). There were four apparently normal sibs and no family history of congenital malformations.

She had unusual facies with marked hirsutes of the forehead (Fig. 1). The eyebrows were thick and joined

Received March 8, 1967. above the bridge of the nose, as in de Lange's syndrome, and the eyes were prominent but otherwise normal. The ears were rather large and low set, there was some hypertrophy of the gums, particularly of the upper jaw, and the hard palate was high arched with a cleft of the entire soft palate. The neck was short with slight webbing. The external genitalia were those of a normal female. There were no flexion deformities of the digits but all limbs were very hypotonic.

She failed to gain weight and a loud praecordial systolic murmur appeared on the 12th day and persisted thereafter. She finally died aged 5 months 4 days.

Necropsy. The child was emaciated and weighed only $1950 \mathrm{~g}$. ( $4 \mathrm{lb} .5 \mathrm{oz}$.). The crown-rump length was $34 \mathrm{~cm}$. and crown-heel $52 \mathrm{~cm}$., while the head circumference was $32 \mathrm{~cm}$.

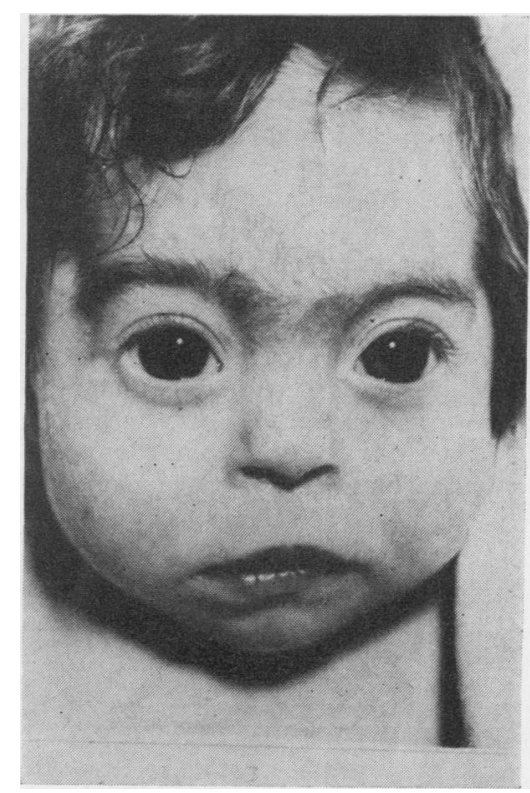

FIG. 1. Facies showing marked hirsutes, 
The heart showed an ostium secundum defect measuring $0.8 \times 0.4 \mathrm{~cm}$. and a high ventricular septal defect measuring $0.6 \times 0.4 \mathrm{~cm}$. The pulmonary valve was bicuspid, but all other valves were normal. The ductus arteriosus was closed.

Each kidney weighed only $7 \mathrm{~g}$. and showed mild dilatation of pelvis and ureter. On histological examination occasional cysts lined by flattened, cuboidal, or columnar ephithelium were demonstrated in the outer part of the cortex. The uterus was small with normal Fallopian tubes. The gonads were only about $0.1 \mathrm{~cm}$. wide and measured $1.6 \mathrm{~cm}$. (right) and $1.2 \mathrm{~cm}$. (left) in length. Microscopically they showed numerous small collections of cells resembling granulosa cells clearly demarcated from the apparently normal ovarian stroma which formed the bulk of both gonads. In spite of the presence of these cells no oocytes could be recognized in the right gonad, and only a few were present in the left ovary.

The pylorus showed moderate hypertrophy of the circular fibres to produce a pyloric tumour measuring $1.3 \mathrm{~cm}$. long and $1.0 \mathrm{~cm}$. diameter. No abnormalities of the central nervous system were found. Death was due to bronchopneumonia.

Dermatoglyphs. The quality of palm prints taken at necropsy was too poor for detailed analysis, but no unusual features were noted in the main patterns and the palmar creases were normal.

\section{Cytogenetic Investigations.}

(a) Sex chromatin observations. (i) Buccal smear (cresyl fast violet stain): A total of 47 out of $223(21 \%$ ) nuclei in oral mucosal cells contained a typical sex chromatin body. This proportion is only slightly below the normal female range $(25-70 \%)$, as determined in this laboratory. (ii) Skin fibroblasts (aceto-orcein stain): $36 \%$ chromatin-positive cells were present after culture for 20 days, $37 \%$ after 34 days, and $33 \%$ after 69 days. These values do not differ significantly from each other or from those in the normal female range (15$60 \%$ ). Three biopsies of normal female skin cultured and processed at approximately the same time produced $19 \%, 28 \%$, and $40 \%$ chromatin-positive cells.

In both oral mucosal cells and fibroblasts the chromatin mass was rather more variable in size than in the normal females but was never unduly small or large.

(b) Chromosome studies. Using standard techniques (Butler, 1965), chromosome preparations were obtained from peripheral blood leucocytes and skin fibroblasts

TABLE

GHROMOSOME COUNTS

\begin{tabular}{l|c|c|c|c|c|c}
\hline & $<45$ & $\begin{array}{c}45 \\
\text { With } \\
\text { Ring }\end{array}$ & $\begin{array}{c}\text { W5 } \\
\text { Without } \\
\text { Ring }\end{array}$ & $\begin{array}{c}46 \\
\text { With } \\
\text { Ring }\end{array}$ & $>46$ & $\begin{array}{c}\text { Near } \\
\text { Tetra- } \\
\text { ploid }\end{array}$ \\
\hline Blood & 1 & 3 & 2 & 47 & - & - \\
Skin & 3 & 2 & 3 & 21 & - & 4 \\
\hline
\end{tabular}

(Table). Cells with less than 45 chromosomes and those with 45 including the ring showed random loss and were considered to be broken cells. Karyotypes of cells with 46 chromosomes (Fig. 2) contained normal groups except for $C(X-6-12)$ and $D(13-15)$. Group $C(X-6-12)$ contained 15 normal members and, in addition, a chromosome with a monocentric ring configuration. Variation in the appearance of the ring is shown in Fig. 3. Its size was estimated to be approximately $85 \%$ of the length of chromosome No. 6, thus indicating only a small deletion of an $\mathrm{X}$ or an autosome of similar size.

Observations were made on the position of the ring chromosome in a series of metaphase figures. On average 12 chromosomes were peripherally situated in each metaphase so that the expected random frequency was $26 \%$. The ring chromosome was truly peripheral in $52 \%$ of all plates (Fig. 4), showing that its distribution was non-random. One Group D chromosome had abnormally long short arms terminating in large satellites.

These investigations were carried out before the use of autoradiographic techniques in this laboratory. We were unable to enlist the co-operation of the parents for further studies.

\section{Discussion}

With one exception (Fisher, 1965) patients with ring $\mathrm{X}$ chromosomes show few congenital malformations. The formation of XO cells by secondary loss of the ring leads to $\mathrm{XO} / \mathrm{XX}_{\mathrm{R}}$ mosaicism and consequently a significant proportion show features of Turner's syndrome (Bishop et al., 1966). The ovaries were only examined in one patient (Lindsten and Tillinger, 1962) and were found to be hypoplastic with reduced numbers of primordial follicles.

Our patient had minor features suggesting Turner's syndrome, including a low hair line and slight webbing of the neck. In addition the ovaries were hypoplastic with a few recognizable oocytes but were quite different from those usually found in cases of gonadal dysgenesis. It is therefore possible that the ring chromosome was derived from an $\mathrm{X}$ chromosome, but it could equally represent one of the autosomes in group $C(7,8$, or 9$)$. The effective deletion in the latter case might then be correlated with the presence of cleft palate, cardiac and renal anomalies, and pyloric stenosis. Unfortunately, in the absence of autoradiographic studies, it was not possible to prove the true identity of the ring chromosome. She possessed a structural variant in group $\mathrm{D}(13-15)$ somewhat similar to that found in the patient of Lindsten and Tillinger (1962). Since approximately $3 \%$ of the general population show minor karyotype variations without phenotype abnormality (Court Brown, Jacobs, and Brunton, 1965), this marker chromosome was probably unconnected with the congenital defects present. 


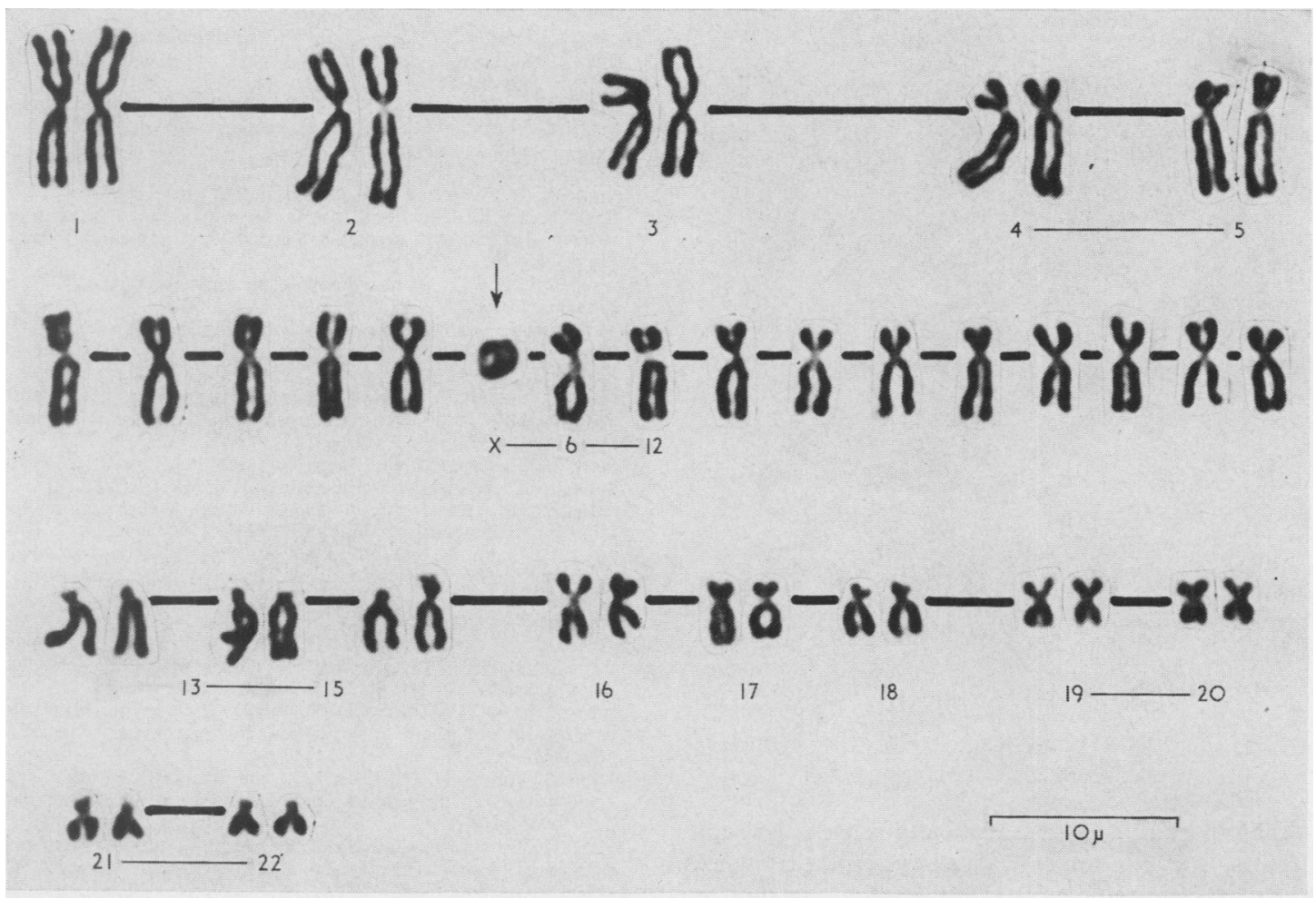

Fig. 2. Karyotype of a cell with 46 chromosomes showing the group X-6-12 ring chromosome (arrowed). Note also the chromosome to the right of the ring with a marked secondary constriction and the group 13-15 chromosome with long short arms.

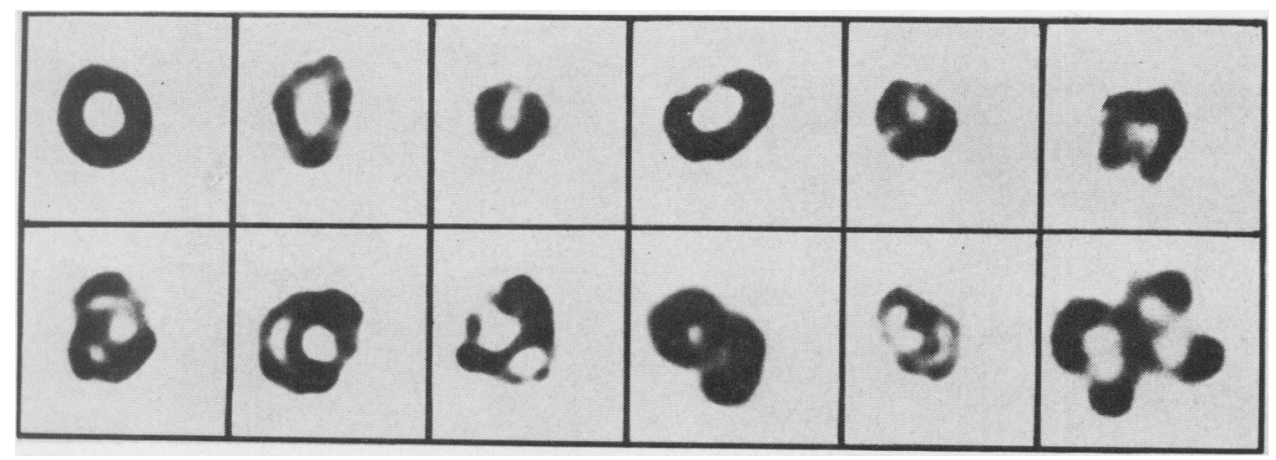

Fig. 3. Ring chromosomes from a series of metaphase figures showing the variation in morphology, including a pair of interlocked rings. $(\times 4280$. $)$

There was no evidence of mosaicism so that one might expect a normal or near normal sex chromatin count even if the defective chromosome were an $\mathrm{X}$ chromosome. In all the ring $\mathrm{X}$ patients reported, low sex chromatin counts could be correlated with $\mathrm{XO} / \mathrm{XX}_{\mathrm{R}}$ mosaicism, the $\mathrm{XX}_{\mathrm{R}}$ line forming not more than $60 \%$ of the total and the majority having far fewer ring positive cells than this (Bishop et al., 1966).

\section{Summary}

An infant is described with unusual facies, low hair line, webbing of neck, low-set ears, cleft palate, hirsutism, and marked hypotonia. Internal defects 


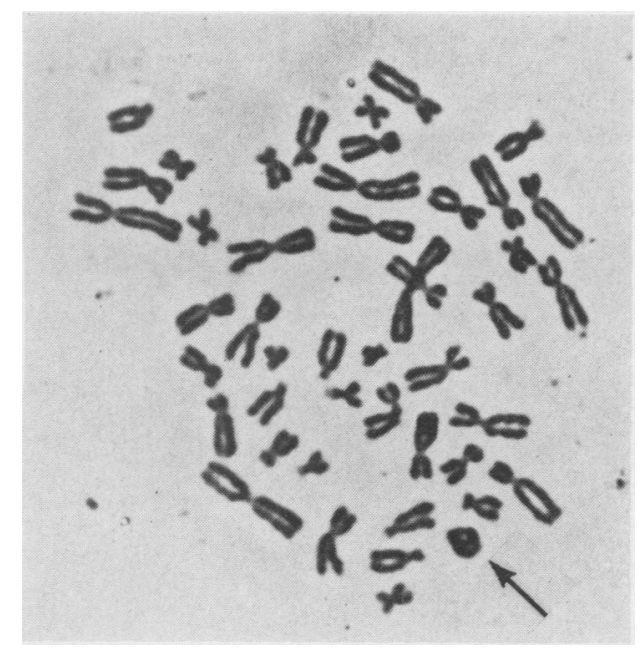

FIG. 4. A cell in metaphase demonstrating the peripheral location of the ring chromosome. $(\times 1500$.

included, cystic kidneys, atrial and ventricular septal defects, pyloric stenosis, and hypoplastic ovaries. She was shown to have a group $\mathrm{C}$ ring chromosome in the vast majority of cells, together with a group D marker chromosome. The identification of the ring as an $\mathrm{X}$ chromosome or an autosome is discussed.

We are grateful to Miss S. Bell, Mrs. F. M. Byron, and Miss P. M. Hopkins for their technical assistance.

\section{REFERENCES}

Atkins, L., Pant, S. S., Hazard, G. W., and Ouellette, E. M. (1966). Two cases with a C-group ring autosome. Ann. hum. Genet., 30, 1.

Bain, A. D., and Gauld, I. K. (1963). Multiple congenital abnormalities associated with ring chromosome. Lancet, $2,304$.

- , - and Farquhar, J. W. (1965). A ring X chromosome in dwarfism. ibid., 1, 820.

Bishop, A. M., Blank, C. E., Simpson, K., and Dewhurst, C. J. (1966). An XO/X ring X chromosome mosaicism in an individual with normal secondary sexual development. $f$. med. Genet., 3, 129.

Butler, L. J. (1965). A micromethod for peripheral blood. Hum. Chromos. Newsl., No. 15, 5.

Court Brown, W. M., Jacobs, P. A., and Brunton, M. (1965). Chromosome studies on randomly chosen men and women. Lancet, 2, 561.

Fisher, G. W. (1965). Ring chromosome mosaicism in a severely subnormal child with multiple congenital malformations. f. ment. Defic. Res., 9, 39.

Genest, P., Leclerc, R., and Auger, C. (1963). Ring chromosome and partial translocation in the same cell. Lancet, 1, 1426.

Gordon, R. R., and Cooke, P. (1964). Ring-1 chromosome and microcephalic dwarfism. ibid., 2, 1212.

Gropp, A., Jussen, A., and Ofteringer, K. (1964). Multiple congenital anomalies associated with a partially ring-shaped chromosome probably derived from chromosome No. 18 in man. Nature (Lond.), 202, 829.

Hustinx, T. W., and Stoelinga, G. B. (1964). A ring-X-chromosome in part of the somatic cells of a patient with some characteristics of the Turner syndrome. Genetica, 35, 1.

Lindsten, J., and Tillinger, K.-G. (1962). Self-perpetuating ring chromosome in a patient with gonadal dysgenesis. Lancet, 1 , 593.

Lucas, M., Kemp, N. H., Ellis, J. R., and Marshall, R. (1963). A small autosomal ring chromosome in a female infant with congenital malformations. Ann. hum. Genet., 27, 189.

Lüers, T., Struck, E., and Nevinny-Stickel, J. (1963). Self-perpetuating ring chromosome in gonadal dysgenesis. Lancet, 2,887 .

Pfeiffer, R. A., and Büchner, T. (1964). Absence of late replication of the human X-ring chromosome. Nature (Lond.), 204, 804

Rohde, R. A., and Tompkins, R. (1965). 'Cri du chat' due to a ring-B (5) chromosome. Lancet, 2, 1075.

Smith-White, S., Peacock, W. J., Turner, B., and Den Dulk, G. M. (1963). A ring chromosome in man. Nature (Lond.), 197, 102.

Turner, B. (1963). Cytogenetic studies in mental retardation. Proc. Aust. Ass. Neurol., 1, 41.

Wang, H. C., Melnyk, J., McDonald, L. T., Uchida, I. A., Carr, D. H., and Goldberg, B. (1962). Ring chromosome in human beings. Nature (Lond.), 195, 733. 